\title{
EFFECT OF GRAPHITE ON MATERIAL PROPERTIES OF SUPERHEATER TUBES MADE OF STEEL 16Mo3 AFTER CREEP EXPOSURE
}

\author{
Šárka STEJSKALOVÁ, Zdeněk KUBOŇ, Gabriela ROŽNOVSKÁ \\ Material and Metallurgical Research, Ltd., Ostrava, Czech Republic, EU, sarka.stejskalova@mmvyzkum.cz
}

https://doi.org/10.37904/metal.2020.3528

\begin{abstract}
Low-alloy steel $16 \mathrm{Mo} 3$ is often used for tubes and other components of the pressure system of a boiler operating at elevated temperature (up to $530^{\circ} \mathrm{C}$ ). Long-term exposure of low-alloy steel components at elevated temperatures inevitably result in some kind of structural degradation; for example, creep cavitation, carbide coarsening and/or spheroidization, and, less commonly, also graphitization. Graphitization can be detected mainly in carbon steels, but also in $16 \mathrm{Mo} 3$ steel where the ferritic matrix is strengthened by Mo in the solid solution. The absence of strong carbide forming elements (typically $\mathrm{Cr}, \mathrm{V}, \mathrm{Nb}$ ) is the principal reason why these steels are susceptible to cementite decomposition and graphitization much more than the other creep resistant steels.

The paper describes microstructure and material properties of superheater $16 \mathrm{Mo} 3$ tube, in which graphite was found after 70.000 hours of exposure at $445^{\circ} \mathrm{C}$. The actual material properties were compared to another tube of the same material delivered in the as-received state. The comparison was based on evaluation and testing of mechanical strength, fracture properties and microstructure. Creep resistance of the steel was studied using small punch creep tests (SPCT).
\end{abstract}

Keywords: $16 \mathrm{Mo} 3$ steel, superheater tubes, graphite, microstructure

\section{INTRODUCTION}

The presented paper deals with the analysis of microstructure as well as material properties of a superheater tube made of $16 \mathrm{Mo} 3$ steel after 70.000 hours of exposure at $445^{\circ} \mathrm{C}$. Previous analysis performed on the similar tube of the same boiler revealed dark particles of irregular shape in the microstructure. The aim of this analysis was to confirm whether these particles are graphitic or not and how they could influence the material properties and creep resistance of the tube.

Graphitization and graphitization failure can be the cause of microstructural degradation and deterioration of mechanical properties especially in carbon and carbon-molybdenum creep resistant steels [1].

\section{GRAPHITIZATION OF BOILER STEELS}

Graphitization can be defined, in general, as the formation of free carbon, C (graphite), in iron or steel. While graphite formed during the solidification process is called primary graphite, when it forms by the transformation of metastable metallic carbides during following solidification, it is called secondary graphite. The most common process of secondary graphitization involves the decomposition of pearlite by transformation of the cementite $\mathrm{Fe}_{3} \mathrm{C}$ at elevated temperature into iron and graphite (eq. 1):

$$
\mathrm{Fe}_{3} \mathrm{C} \longrightarrow 3 \mathrm{Fe}+\mathrm{C}
$$

The age-related graphitization of carbon and/or low-alloy steel in elevated-temperature fossil plants (or other) service is an example of secondary graphitization. In contrary to expected primary graphitization (e.g. in the 
case of cast iron), the in-service phenomenon in carbon and low-alloy steels is unintentional and sometimes results in material properties change that can shorten lifetime of the operating component [1].

Existence of graphite in boiler steels was proven long time ago and mainly concerned carbon and molybdenum steels. FARROW [2] summarized these results in his work, which mentioned cases of graphitization of C-Mo steels and subsequent pipeline accidents in conventional power plants. Graphite formed by the decomposition of cementite can precipitate in a steel in three different morphologies:

- $\quad$ randomly distributed nodules similar to malleable cast iron,

- $\quad$ segregation bands along isotherms generated during preheating or previous temperature effect,

- $\quad$ dispersed particles along the deformation bands.

The most dangerous is the presence of graphite in segregation bands because this form of graphite is preferred in heat-affected zone of welded joints. This is a direct effect of the heating of this area to a temperature around the $A_{c 1}$ temperature.

Graphitization itself consists of nucleation and growth of particles and involves the decomposition of cementite, the diffusion of carbon and its precipitation at suitable nucleation sites. Similarly to the other transformation processes involving the nucleation and growth of a new phase, the temperature dependence of graphitization has a maximum, typically at a temperature range $550-600^{\circ} \mathrm{C}$, but the occurrence of graphite, especially in non-alloyed steels, can be observed even at temperatures around $400{ }^{\circ} \mathrm{C}$. Graphitization of steels can be relatively easily prevented by the addition of either alloy or trace elements with a high affinity to carbon, where the resulting secondary carbides have a sufficiently high thermodynamic stability. These elements can also reduce the mobility of the carbon and its diffusion rate and thus help to prevent graphitization. In contrast, some accompanying elements and gases stimulate graphitization by increasing the density of potential nucleation sites in the steel for the formation of graphite nuclei.

Silicon, nickel, copper, boron and especially aluminum significantly accelerate the graphitization of steel. These elements are generally characterized by a low affinity for carbon and so they increase the chemical activity of carbon in steel. It has been shown that, in particular, steels with higher aluminum content are highly susceptible to graphitization. Local plastic deformation can significantly affect the process of graphitization of steels a very significant effect is also attributed to local stresses and deformations in heat-affected zones of the weld, where continuous mesh graphite can cause destruction of strength and integrity of the weld.

Steel 16 Mo3 is alloyed with molybdenum from 0.25 to $0.35 \mathrm{wt} \%$. Except of carbon steels this steel grade is the only one among low-alloyed creep resistant steels which can be susceptible to graphitization due to relatively low molybdenum concentration when substantial part of it remains in the solid solution and does not form special carbide. The influence of aluminum is critical even in this case, as was observed many times $[3,4]$ and the significant effect of deformation on the kinetics of graphitization of steel was confirmed, too. The presence of non-metallic inclusions itself is not necessary condition to form graphite in the microstructure, but that the presence of a sufficient amount of carbon is probably crucial. The effect of graphite presented at grain boundaries lies in facilitation of interconnection of the intergranular defects and thus the reduction of the service life of components operating in the creep conditions.

However, the exact effect of aluminum in the base metal (i.e. not in the welded joint) on graphitization and the mechanism by which graphite reduces the heat resistance of steels has not yet been clearly demonstrated. There are two main effects:

1) decomposition of carbides and carbon removal from the steel with subsequent "softening" of the matrix accompanied by excessive plastic deformation of more than $100 \%$,

2) local interconnection of defects along grain boundaries powered by easy crack propagation through graphite particles.

The effect of aluminum in low-alloy boiler steels depends on the form of its presence in the steel, i.e. on the ratio of aluminum bound in oxides and/or nitrides and aluminum dissolved in the solid solution. While a part of 
aluminum content bound to oxygen and nitrogen in the steel has a positive effect on refining the austenitic grain and increasing the toughness of the steel, the effect of the excess (above-stoichiometric) aluminum content is exactly the opposite. Aluminum in higher concentration promotes the graphitization of steel, which makes it significantly different from other deoxidizing elements that form stable carbides and /or nitrides.

\section{EXPERIMENTAL MATERIAL}

The properties of a superheater tube made of $16 \mathrm{Mo} 3$ steel, where graphite occurred in the structure after 70.000 hours exposure at $445^{\circ} \mathrm{C}$, were analysed. Material properties of this tube were compared to the tube of the same grade in the as-received state, as well as to the properties of a tube of the same superheater tested after 56.000 hours of exposure in 2012. The mechanical properties, fracture properties and microstructure were evaluated and assessment of creep properties was performed using small punch test method.

Chemical composition of both exposed tubes and the as-received tube is given in Table 1 together with the nominal chemical composition of the steel $16 \mathrm{Mo} 3$ stated in the material standard.

Table 1 Chemical composition of $16 \mathrm{Mo} 3$ tubes [wt\%]

\begin{tabular}{|c|c|c|c|c|c|c|c|c|c|c|}
\hline Tube & $\mathbf{C}$ & $\mathbf{M n}$ & $\mathbf{S i}$ & $\mathbf{P}$ & $\mathbf{S}$ & $\mathbf{M o}$ & $\mathbf{C r}$ & $\mathbf{A l}$ & $\mathbf{N}$ & $\mathbf{C u}$ \\
\hline 16Mo3 exposed - 56.000h & 0.20 & 0.65 & 0.28 & 0.010 & 0.022 & 0.35 & 0.01 & - & - & \\
\hline 16Mo3 exposed - 70.000 & 0.21 & 0.58 & 0.26 & 0.008 & 0.008 & 0.28 & 0.05 & 0.023 & 0.010 & \\
\hline $\mathbf{1 6 M o 3}-$ as received & 0.19 & 0.69 & 0.25 & 0.009 & 0.005 & 0.27 & 0.19 & 0.018 & 0.013 & \\
\hline 16Mo3 - ČSN EN 10 216-2 [5] & $\begin{array}{c}0.12 \\
0.20\end{array}$ & $\begin{array}{c}0.40 \\
0.90\end{array}$ & $\begin{array}{c}\text { max. } \\
0.35\end{array}$ & $\begin{array}{c}\text { max. } \\
0.025\end{array}$ & $\begin{array}{c}\text { max. } \\
0.010\end{array}$ & $\begin{array}{c}0.25 \\
0.35\end{array}$ & $\begin{array}{c}\text { max. } \\
0.30\end{array}$ & $\begin{array}{c}\text { max. } \\
0.040\end{array}$ & - & $\begin{array}{c}\text { max. } \\
0.30\end{array}$ \\
\hline
\end{tabular}

The chemical composition of all tubes is in good agreement with the nominal composition of steel 16 Mo3 according to standard. The difference between both creep exposed tubes confirms the fact, that both tubes were produced from different heats. Tube after 70.000 hours and in as-received state have very similar composition, they differ slightly in the aluminum content. The aluminum content of these tubes is lower than the limit $0.025 \mathrm{wt} \%$, which is regarding as "safety" aluminum amount considering graphitization [6].

\section{RESULTS OF PERFORMED ANALYSES}

The mechanical properties, especially tensile strength and hardness again confirmed the fact that the original heats were different and, at the same time, they had higher yield strength than the tube tested in the asreceived condition and, therefore, also higher yield-to-tensile strength ratio. However, it is difficult to access if it is the trend or the only random feature. (see Table 2).

Microstructure of exposed tube after 70.000 hours was evaluated on the cross section of tube. There were revealed numerous graphitic particles in the nodular form especially in the middle part of tube wall (Figure 1).

Table 2 Mechanical properties of 16 Mo3 tubes

\begin{tabular}{|c|c|c|c|c|c|}
\hline Tube & $\mathbf{R}_{\mathrm{p} 0.2}[\mathrm{MPa}]$ & $\mathbf{R m}[\mathrm{MPa}]$ & $\mathbf{A}[\%]$ & $\mathbf{R}_{\mathbf{p} 0.2} / \mathbf{R}_{\mathbf{m}}[-]$ & HV [-] \\
\hline 16Mo3 exposed - 56.000h & 424 & 487 & 33.1 & 0.89 & 177 \\
\hline 16Mo3 exposed -70.000h & 348 & 445 & 38.5 & 0.78 & 135 \\
\hline 16Mo3 - as received & 326 & 531 & 31.7 & 0.61 & 190 \\
\hline 16Mo3 - ČSN EN 10 216-2 [5] & min. 280 & $450-600$ & $\min .22$ & - & - \\
\hline
\end{tabular}



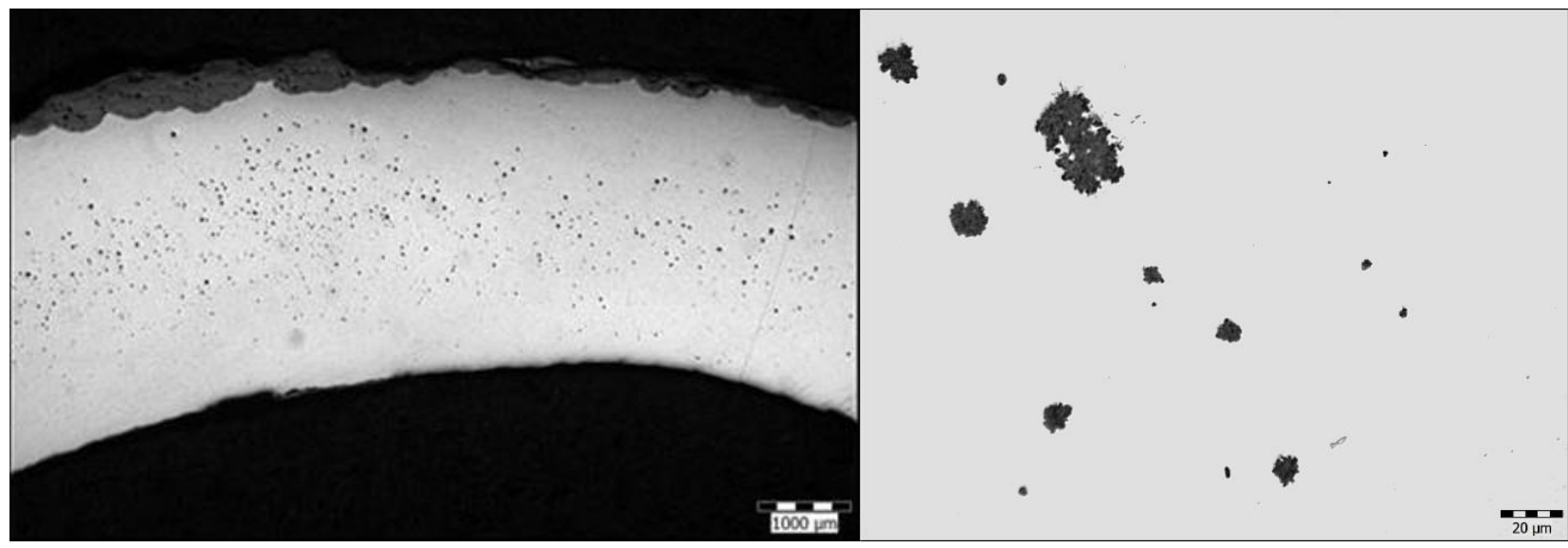

Figure 1 Graphite nodules in the wall of exposed tube $(70.000 \mathrm{~h})$ - polished

The microstructure of tube consists of ferrite with coarse carbides on its grain boundaries and just locally carbide precipitate as decomposed perlite/bainite (see Figure 2).

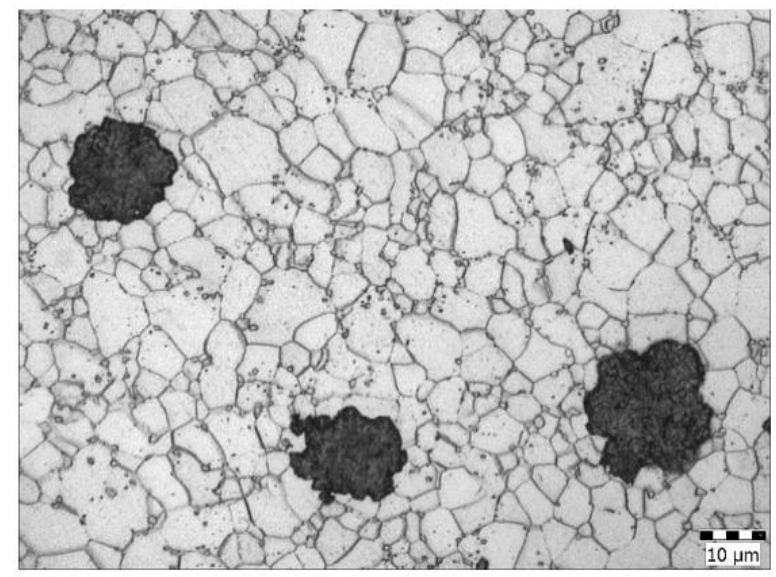

Figure 2 Graphite particles in the ferritic structure

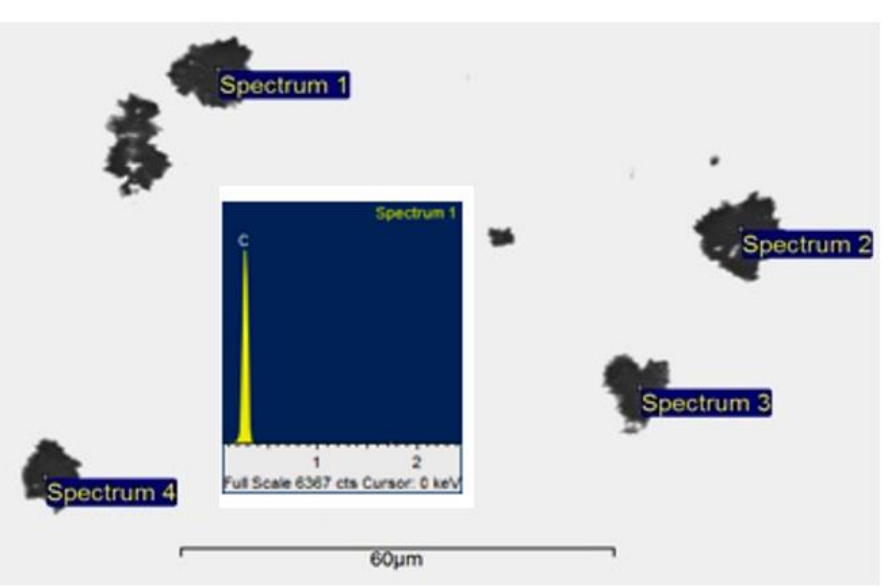

Figure 3 Typical EDX spectra of graphite partiles

Presence of graphite in the structure was confirmed by X-ray microanalysis which confirms that they are realy graphite particles. The typical EDX spectra are shown in the Figure 3. The occurrence of graphite in the structure of the exposed tube probably influenced the mechanical properties, although did not lower impact toughness (see Table 3). The impact toughness was evaluated using subsized specimens $5 \times 2.5 \times 32 \mathrm{~mm}$ (tube $7.000 \mathrm{~h}$ ) and $5 \times 3 \times 32 \mathrm{~mm}$ (as-received tube).

Exposed tube showed very similar impact toughness as the as-received tube, regardless the presence of graphite particles in the microstructure. The analysis of fracture surface performed by electron microscope JEOL JSM-5510 showed transgranular ductile fracture with prevailing small dimples, but some large and deep dimples were observed, too, see Figure 4. These large holes could be initiated on the particles of graphite but due to the fact that they were deep, it was not possible to perform EDX microanalysis of the possible particle inside them.

Table 3 Impact toughness of as-received and exposed tubes

\begin{tabular}{|c|c|c|c|c|}
\hline Tube & $\mathbf{1}$ & $\mathbf{2}$ & $\mathbf{3}$ & $\mathrm{KCV}\left[\mathrm{Jcm}^{-2}\right]$ \\
\hline 16Mo3 exposed 70.000 $\mathrm{h}$ & 107 & 145 & 104 & $\mathbf{1 1 9}$ \\
\hline 16Mo3 - as-received & 109 & 108 & 100 & $\mathbf{1 0 6}$ \\
\hline
\end{tabular}




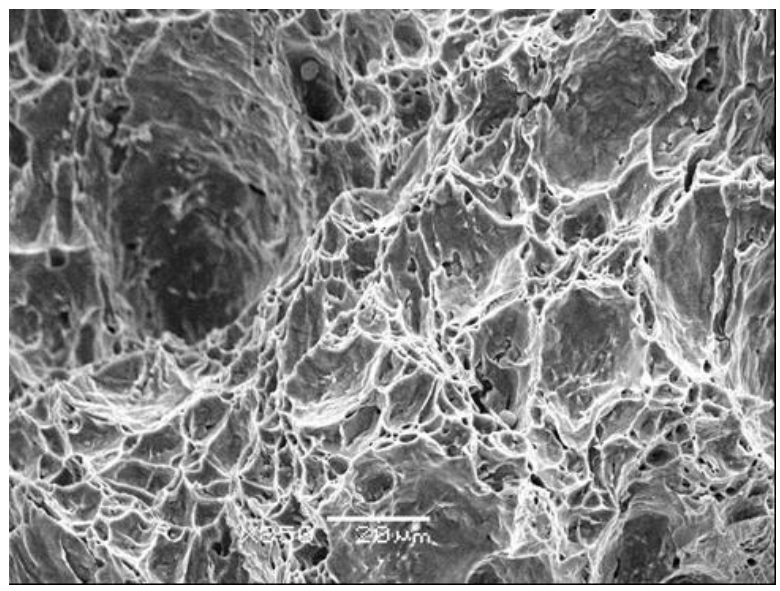

Figure 4 Fracture surface of Charpy-V impact test of exposed tube

\section{RESULTS OF SMALL PUNCH CREEP TESTS}

Small punch creep tests (SPC tests) were performed on discs of $\varnothing 8 \mathrm{~mm} \times 0.5 \mathrm{~mm}$ at temperature $575{ }^{\circ} \mathrm{C}$ in the load range from 330 to $500 \mathrm{~N}$. All SPC tests were performed under a protective argon atmosphere on SPUTT 500 testing machine designed and developed in MMV Ostrava.

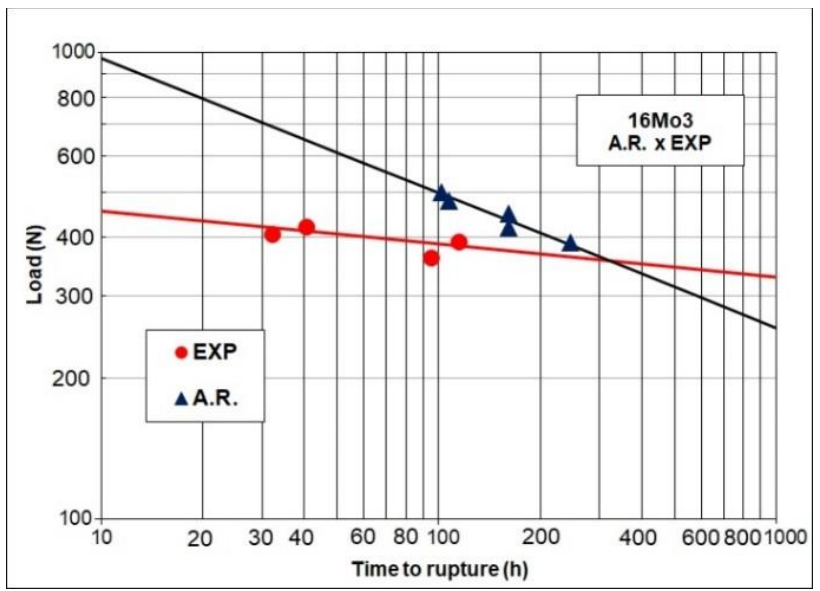

Figure 5 Relation between time to rupture and load (A.R. $=$ as-received, EXP $=$ exposed)

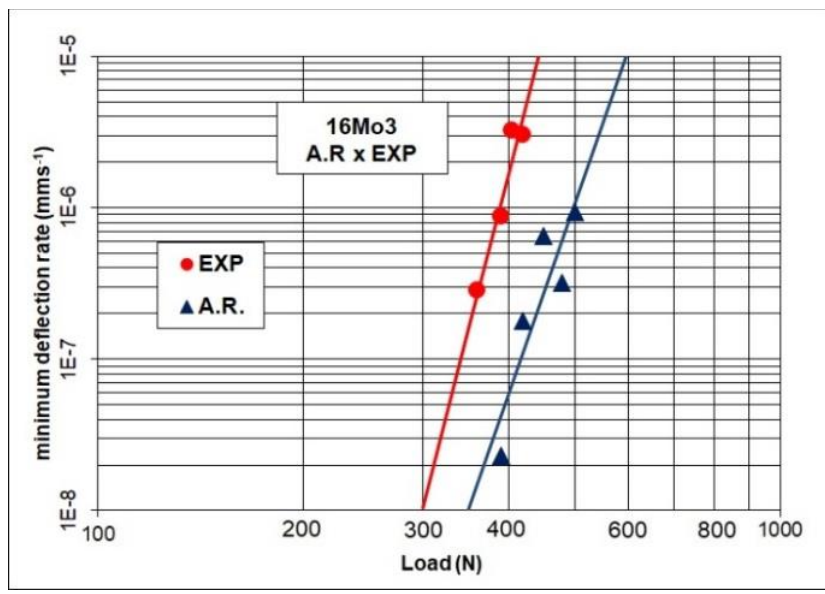

Figure 6 Load dependence of minimum deflection rate $(A . R .=$ as-received, EXP $=$ exposed $)$

The results are stated in Figure $\mathbf{5}$ in the form of relation between load and time to rupture and in Figure $\mathbf{6}$ as load dependence of minimum deflection rate. The results for the exposed tube have unlikely low slope, which could be caused due to graphitization and greater scatter of the individual results. What is however evident, is the fact that all test specimens in the as-received state had for the same loading longer time to rupture as well as lower minimum deflection rate, in general higher creep resistance.

\section{DISCUSSION}

The analysed 16Mo3 tube had exposure parameters and chemical composition that would not necessarily lead to graphitization. It has relatively low aluminum content and was operated at temperature significantly lower than the maximum graphitization temperature $\left(550-600^{\circ} \mathrm{C}\right)$. Graphitization was also observed in the whole tube, not only in heat affected zone or their critical parts of the structure. In spite of this fact graphitization occurred, which may mean that either 
- the temperature of tube exposure could be probably higher. This possibility is supported by the microstructure that shows some signs of exposure at higher temperature than $445^{\circ} \mathrm{C}$. Provided that the tube was exploited at declared low temperature then there had to be still preserved some pearlitic/bainitic blocks in the microstructure and the level of structural not only the mixture of ferrite and carbides.

- $\quad$ the most frequently reported threshold aluminum content $0.025 \mathrm{wt} \%$ for graphitization in C-Mo steels seems to be not enough to prevent graphitization of C-Mo steel during common operating conditions in power plants. The occurrence of graphite particles in the structure caused the decrease of hardness, resp. tensile strength. On the other hand, level of impact toughness is at the same level as in state asreceived, which could support the theory that nodular form of graphite is benign, although creep properties were affected by presence of graphite in the structure.

\section{CONCLUSION}

The paper deals with graphitization of superheater tube made of 16 Mo 3 steel exploited in common operating conditions of conventional power plants. The occurrence of nodular graphite particles in the middle of wall tube effected mechanical and creep properties while the impact toughness of exposed tube corresponds to the level one of state as-received.

\section{ACKNOWLEDGEMENTS}

This paper was created in the frame of the Institutional support for long-term and conceptual development of a research organization in 2019, provided by the Ministry of Industry and Trade of the Czech Republic.

\section{REFERENCES}

[1] FOULDS, R., VISWANATHAN, R. Graphitization of Steels in Elevated-Temperature Service. J. Mater. Eng. Perform. 2001, vol. 10, no. 4, pp 484-492.

[2] FARROW, M. The graphitization of low alloy steels. Steels for reactor pressure circuits. Special Report No. 69, The Iron and steel institute. 1961, pp. 89-100.

[3] FABRITIUS, H. Stahl und Eisen. 1971, p. 1073-1081.

[4] SOBOTKA, J., VODÁREK, V., TOMÁŠOVÁ, M., SOBOTKOVÁ, M. K otázce vzniku grafitu při creepu nízkolegované oceli 15 020. Hutník. 1986, vol. 36, pp. 267-274.

[5] ČSN EN 10216-2+A2 Bezešvé ocelové trubky pro tlakové nádoby a zařizení - Technické dodací podmínky - Část 2: Trubky z nelegovaných a legovaných ocelí se zaručenými vlastnostmi při zvýšených teplotách. 2014.

[6] BHARADVAJ, M. Study of Graphitization in Carbon Steel Weldments for Remaining Life Assessment. PhD diss., Knoxville: University of Tennessee, 2016. 